\title{
CLAIMS OF SCIENTIFIC APPROACH \\ IN AN ENGLISH LESSON TRANSCRIPT
}

\author{
Ahmad Munir \\ Jurusan Bahasa dan Sastra Inggris FBS Unesa \\ ahmadmunir@unesa.ac.id
}

\begin{abstract}
As the generic approach for teaching all subjects in the 2013 Curriculum, five stages of Scientific approach (SA) are subject to adaptation (Permendiknas 103/2014). In response to this, English lessons have married it with genre-based approach (GBA) through stages of instruction, namely building context or knowledge of the field, modeling of text and deconstructing it, joint construction of text, and independent instruction of text. This paper reports an analysis of an English lesson transcript which has been claimed as applying scientific approach in Hafidah's (2014) study. Through a qualitative analysis, all the classroom language used by both teacher and her students were categorized in to their intended five SA stages, GBA stages and their pedagogical intentions (Johnson, 1990). The whole classroom language use was then analysed for its inductivedeductive reasoning. Results show that there is little evidence of scientific approach in that lesson transcript.
\end{abstract}

Keywords: scientific approach, lesson transcript, reasoning.

\begin{abstract}
Abstrak
Sebagai pendekatan untuk mengajar semua mata pelajaran di Kurikulum 2013, lima tahap pendekatan ilmiah mungkin untuk adaptasi (Permendiknas 103/2014). Dalam hal in, mata pelajaran bahasa Inggris menggabungnya ke pendekatan berbasis genre (GBA) melalui tahapan membangun konteks atau pengetahuan tentang lapangan, pemodelan teks dan mendekonstruksi itu, menyusun teks bersama-sama, dan menyusun teks secara mandiri. Makalah ini melaporkan analisis transkrip pelajaran yang telah diklaim sebagai menerapkan pendekatan ilmiah dalam studi Hafidah (2014). Melalui analisis kualitatif, semua bahasa kelas yang digunakan oleh guru dan siswa-siswanya dikategorikan dan dimasukkan dalam lima tahap pendekatan ilmiah mereka, tahapan GBA dan niat pedagogis guru (Johnson, 1990). Seluruh penggunaan bahasa kelas kemudian dianalisis untuk penalaran induktif-deduktif nya. Hasil penelitian menunjukkan bahwa ada sedikit bukti dari pendekatan ilmiah dalam transkrip pelajaran.
\end{abstract}

Kata kunci: pendekatan ilmiah, transkrip pelajaran, penalaran 


\section{INTRODUCTION}

Curriculum renewal is an inevitable activity in countries which seek to improve their educational quality. It is also meant to revise the existing curriculum. As in curriculum development, curriculum renewal also include processes of "needs analysis, situational analysis, planning learning outcomes, course organization, selecting and preparing teaching materials, providing for effective teaching, and evaluation" (Richards, 2001: 41). However, what specific aspect to revise, when is the best time to revise depend on the perspectives of the stakeholders, including policy makers, needs analysts, methodologists, materials writers, teacher trainers, teacher, learner, government, parents and students (Richards, 2001).

Indonesian School curriculum is also renewed recently by introducing the 2013 Curriculum. This curriculum is to replace the 2006 Curriculum gradually. It is expected to reflect the current needs of Indonesian educational goals. A massive introduction and training for teachers on this Curriculum has been made through Training for Trainers up to in-house training and clinical coaching.

What characterizes this introduction of curriculum is its prescriptive through so many Ministerial decrees in 2013 and 2014. all these decrees stipulates core competences, basic competences, contents, design of learning activities, and evaluative measures for determining the achievement of core competence for all subjects in Junior and Senior High schools including English. According to Richards (2001: 42), such a renewal in English language curriculum impact of the stake holders in different ways as follows: policy makers may have to change policy documents, needs analysts and methodologists may have to change the syllabus, materials writers have to change teaching materials, teacher trainers have to prepare new teacher training program, teachers have to change their teaching acts, and learners too have to change their learning acts.

In other words, implementing new curriculum may change not only what pupils learn, but also how they learn it, how teachers help them learn, using what supporting materials, styles and methods of assessment, and in what kind of facilities. Lemke (1989) reiterates that new curriculum may change the educational discourse in the in terms of what the teachers have to say and how to 
say it so that they reflect the new approach a new curriculum carries and the students have also to understand these educational discourse.

The educational discourse can also be called classroom language, language used by teachers "typically...when giving instructions, explaining, asking questions,..., responding to and evaluating students' contributions, signaling the beginning and end of activities and lesson stages, and so on" (Cullen, 2001:29). In English lessons, classroom language refers to English words or expressions used by teachers as the main language of daily communication in the language classroom (Munir, 2012:35). Classroom language expressions introduced in books on classroom language [e.g. Hughes et.al (2007), Salaberri (1995), and Slattery and Willis (2001)] mainly cover interpersonal aspects of classroom language (i.e., controlling, organising and motivating) and partly cover pedagogical aspects of it (i.e. operative). Pedagogical aspects of classroom language include operative (getting pupils to do something), interactive (getting pupils to say something) and informative modes (telling things to the pupils) (Johnson, 1990). Yet, almost none of the books present classroom language expressions for "interactive and informative" modes. What these book cover are expressions used for interpersonal aspects of classroom language for organising the lessons (opening, disciplining, motivating, and closing the lessons). The expressions for running the pedagogical aspects of classroom language which deals with the subject matter of the lessons are left to teachers to create by themselves.

As previously indicated, the new 2013 Curriculum introduced a new approach for teaching, called the Scientific Approach based on the Miniterial Decree no 65/2013 and 103/2014, which states "proses pembelajaran menggunakan pendekatan ilmiah" (Permendikbud 103/2014). The curriculum further stipulates its stages as follows: "mengamati (observing), menanya (questioning), mengumpulkan informasi/mencoba (collecting information/ experimenting), menalar/mengasosiasi (reasoning/associating), dan mengomunikasikan (communicating)". While these stages are generic, the decree allows for adaptation saying it could be adapted to the characteristics of each lesson "Dapat disesuaikan dengan kekhasan masing-masing mata pelajaran." 
In response to this permission, Teacher Book of When English Rings The Bell (Revised Edition) for Grade VII (Kemendikbud, 2014: 12) makes implementation guidelines as follows:

1. Observing stage includes activities of listening to spoken texts (audio/video) and reading short/long functional texts, including an observation sheet, in order to explore their social functions, text structure, language features.

2. Questioning stage includes activities of reconstructing concepts of social functions, text structure, language features of the observed texts.

3. Collecting information/experimenting stage includes activities of internalization of the learned concepts by applying them in real language use in the class, i.e. producing texts similar to what they observe.

4. Reasoning/associating stage includes activities of employing the concepts of social functions, text structure, language features to other similar texts to strengthen the concepts.

5. Communicating stage includes activities of showing their knowledge of social functions, text structure, language features and language skills of producing texts orally and in writing.

The above guidelines clearly represent the implementation of genre-based approach (Feez and Joyce, 1998). This is the adaptation of Scientific Approach (SA) through Genre-Based Approach (GBA) in English lessons. This is clearly seen in the foreword in Teacher Book of When English Rings The Bell (Revised Edition) for Grade VII (Kemendikbud, 2014: iii), stating that "Penyajiannya adalah dengan menggunakan pendekatan pembelajaran berbasis teks, baik lisan maupun tulis, dengan menempatkan bahasa Inggris sebagai sarana berkomunikasi“".

The adaptation of scientific approach, therefore, requires justifications. As the Ministerial decrees do not define what SA is but elaborating it into its stages, it is important to refer to a more general definitions of SA. Scientific approach in theoretical textbooks generally refers a method of acquiring knowledge in which investigators move inductively from their observations to hypotheses and then deductively from the hypotheses to the logical implications of the hypotheses (Ary et al., 2010: 8). 
"These investigators deduce the consequences that would follow if a hypothesized relationship were valid. If the deduced implications are compatible with the organized body of accepted knowledge, researchers then further test them by gathering empirical data. On the basis of the evidence, they accept or reject the hypotheses" (Ary et al., 2010: 8).

Thus, the main idea of SA is reasoning to understand natural and social reality through inductive-deductive thinking.

The question is then "Do the characteristics of English lessons in the 2013 Curriculum represent this inductive followed by deductive reasoning?" GBA approach aims at teaching how to create texts (spoken and written) as they are used by its speakers in their contexts. In other words it aims at developing discourse competence (Badan Standar Nasional Pendidikan, 2006). The learning cycle in the genre approach (Feez \& Joyce, 1998: 28; Hammond, 2001) includes oral and written cycle, in which it consists of four stages:

1. Building the Context or Knowledge of the Field (BKoF) by introducing learners to "social context of authentic model of the text type being studied" through "pictures, audio visual material, realia, excursions, guest speakers. Etc".

2. Modeling (MoT) and Deconstructing the Text (DecoT) by "investigating the structural patterns and language features of the model" at "text-level, clause-level and expression level".

3. Joint Construction of Text (JCoT) by "contributing to the construction of whole example of the text-type then gradually reducing teacher's contribution".

4. Independent Construction of Text (ICoT) by letting students "work independently with the text"

In Knapp and Watkins (2005: 78) only three main stages of GBA are emphasized, namely Modelling of text, Joint contrcution of text and Independent construction of Text.

These stages have been accommodated in Teacher Book of When English Rings The Bell (Revised Edition) for Grade VII (Kemendikbud, 2014: 11). The book clearly states that the scenario of English lessons should include: 
a. Observing or following text models, authentic texts which are used/ $\mathrm{read} /$ listened to/ exemplified by teacher.

b. Deconstructing the text models for analytical purposes, i.e. analyzing its social functions, text structure, and language features, including exploration of their meanings.

c. Producing texts by copying in hand writing or other ways so that it is ready for displays.

d. Presenting the texts produced in the previous stage through portfolios, displays, wall magazine.

The four stages of GBA previously presented are similar to the lesson scenario suggested to be implemented by teachers in classroom. The BKoF and MoT are incorporated in the first step of the lesson scenario (Observing or following text models), while the deconstruction of text (DecoT), which is part of modeling of text becomes the second step of lesson scenario (Deconstructing the text models). The third and fourth stages in GBA, i.e. JCoT and ICoT are incorporated in the third step in the lesson scenario (producing texts). The fourth step in the lesson scenario has no direct reference to the stages of GBA.

Activities during $\mathrm{BKoF}$ and MoT plus DecoT require students to observe phenomenon to finally draw conclusions of patterns of the phenomenon under observation. This is inductive reasoning as previously explained (Ary et.al., 2010). While the joint construction activities allow the students with teacher's assistance to apply the pattern they obtained previously in to their own text. This means they reconstruct/reproduce similar text jointly and on their own. These are deductive reasoning. All these suggest that both GBA and lesson scenarios of English lesson based on the 2013 Curriculum are in line with SA.

Nevertheless, the implementations of English lessons based on the 2013 Curriculum have shown variations of SA. For example, Pahlevi's (2014) study found that the teacher under study implemented all the four stages of SA with different degrees of success. For example, in the questioning phase, the teacher's activities in this phase were less effective that those in the collecting information/exploring stage (Pahlevi, 2014). The teacher did not apply communicating activity properly. Similarly, Hafidah's (2014) study found that the teacher implemented all the stages of SA in the teaching of English writing in sequence imperfectly. It was not explained in Hafidah's (2014) study what was the imperfections. Yet, at other parts of her report, she acknowledged the teachers' 
success in encouraging students to see real phenomenon, to listen to some information by explaining to the material, to develop critical thinking skill in responding to a problem, to involve in the discussion, to be skillful in giving logic and systematic answers although she does not encourage her students to raise questions to make them to link the concepts with what is being observed (Hafidah, 2014).

Based on the results of these studies, it is clear that they have made superficial analysis of the SA implementation. They only looked for the characteristics of teachers' actions based on the five stages of SA. Nevertheless, they have not yet seen teachers' actions from the meanings of their activities, in a holistic way--from the whole lessons. In other words, these studies have not yet explored the inductive-deductive reasoning, which underlies the scientific approach. Therefore, this small scale study was conducted to explore in depth the reasoning represented by teacher's use of classroom language. Specifically, this study analyses one lesson transcript already reported in Hafidah's (2014) study by using the lenses of inductive-deductive reasoning, stages of SA and GBA.

This study is "qualitative, interpretive" (Cohen, et al., 2007, p.21) as it explores teacher's experience and its meaning for them and how the meaning of their experience has been formed (Corbin \& Strauss, 2008), i.e. using the eyes of the participants (Cohen, et al., 2007). The data were secondary data, i.e. the first lesson transcript in Hafidah's (2014: 125-129) Appendix 9 of her thesis. The lesson was taught by a female English teacher of year $\mathrm{X}$ in a state senior high school in Madura, East Java. The teacher had been trained as model teacher for the implementation of the 2013 Curriculum.

The transcript was made by Hafidah (2014) following simple transcription system and the aim of analysis was not on conversation analysis (Richards, 2003: 199). For the purpose of ease in reference in this study, the original transcription was modified by assigning numbers to the lines of teachers and lines of students. In doing so, the transcriptions could be referred to during the analysis.

To analyse the transcription, each line of teachers and of students was read thoroughly to get its intentions, i.e. what did the teacher want by saying this or that? What did the students mean by answering/saying this or that? The judgement 
of intentions was based on Johnson's (1990) classification previously mentioned. Intentions were used to classify the turns into stages of SA and GBA. Using these classifications, in-depth analysis of the inductive-deductive reasoning in the whole lesson was made. The results of this analysis were judgements whether or not the lesson had implemented scientific approach. These data analyses procedures were in line with definition of qualitative research as "a process of examining and interpreting data in order to elicit meaning, gain understanding, and develop empirical knowledge" (Corbin \& Strauss, 2008:1).

\section{DISCUSSION}

The lesson transcript in Appendix 9 of Hafidah's (2014) research report contains 101 lines of exchanges between teacher and students in the transcript, consisting of 51 teacher's roles and 50 students roles (teacher's roles are in odd numbers, while those of students are in the even numbers). These do resonate with the objective of the lesson 'to write a written description of friend'.

Superficial analysis of these lines produced the following results:

1. Scientific Approach (SA) stages: observing activities (lines 7-54), questioning (lines 55-78), experimenting (lines 79-88), associating activities (89-96), and communicating the results of their work (lines 97-101)

2. Genre-Based Approach (GBA) stages: building context or knowledge of spoken text (lines 7-56), deconstruction of written text (lines 5784), and independent construction of text (lines 85-101).

3. Teacher's intentions: organizing (once), motivating (once), operative (13 times), interactive (21 times), and informing (once)

Looking at the implemented SA stages above, it is obvious that the teacher had fulfilled all the expected stages of SA. That indicates that the teachers implemented all the five stages: observing, questioning, experimenting, associating, and communicating. This superficial analysis supports Hafidah's (2014) claims that stages of SA implemented by the teacher are accurate. However, the stages of GBA implemented by the teacher are incomplete. The teacher implemented three out of four stages, namely, Building 
context/knowledge of the field $(\mathrm{BKoF})$, deconstruction of text (DecoT) and Independent Construction of Text (ICoT). The teacher skipped two main stages: Modeling of Text (MoT) and Joint Construction of Text (JCoT).

In depth analysis of the implementation of GBA show discrepancy among the stages of GBA implemented by the teacher. For example, the context built by the teacher in the BKoF was spoken text (oral description of peers), not the same as the deconstructed text, in which the teacher drew students' on the characteristics of the written text. This is not in line with what Feez and Joyce (1998) and Knapp and Watkins (2005) explain, in that the text model should be deconstructed.

As a result of different text type being deconstructed, the ICoT activities produced written text. This is another result of deep analysis. Although there was no modeling of written text introduced in the lesson, the teacher assigned the students to produce written description, which was not of 'the same' topic introduced in the BKoF.

What makes the GBA implementation not accurate following what Feez and Joyce (1998) and Knapp and Watkins (2005) elaborate is the missing JCoT. This stage is very crucial for the implementation of GBA as this is the heart of scaffolding to bring students to their Zone of Proximal Development as part of the underlying sociocultural theory of learning (Feez \& Joyce, 1998; Hammond, 2001). "Through joint construction, the teacher and student develop texts together and share responsibility for performance until the students have the knowledge and skills to perform independently and with sole responsibility" (Feez \& Joyce, 1998: 27). The teacher should not let the student create text independently until they are ready. What happened in the transcript was that students seemed to be able to create texts on their own. However, the discussion below will show that it was glossing only.

The facts that there is discrepancy among the stages of GBA implemented by the teacher in the lesson and that there are missing Modelling of Text and Joint Construction of Text have made it hard to say that the teacher essentially implemented scientific approach. 
Other findings which support this early conclusion can be found by doing an analysis on teacher's intentions articultaed through her using classroom language expressions. Teacher's classroom language expressions reveal what reasoning was actually employed by the teacher. As scientific approach employs inductive then deductive reasoning, the activities in the lesson should also reflect these. By looking at the frequency of modes of intentions above, it is indicative that the teacher has been asking students to 'say' things (interactive) most of the time (21 times). The teacher also frequently asked students 'do' things (operative) (13 times). Little explanation (informing) was made by the teacher (once).

In depth analysis of these intentions, however, show little indications of inductive-deductive reasoning. Evidence for these can be seen in the following extracts. Lines 7-54 are mostly interactive, in which the teacher asked the students to 'describe' somebody orally as seen in Extract 1 below.

Extract 1

7 Teacher : ......... How do you know about Kresna?

8 Student : He's like Pasha ungu

Student : Pointed nose.

9 Teacher : Yeah, He's like Pasha Ungu.

10 Student : No.

Extract 1 show that teacher's intention is to elicit students to produce description orally. However, the teacher's question "How do you know about Krisna?" does not require students to describe Kresna. The rest on the lines up to line 54 have similar intentions. In those lines, students' spoken descriptions are possibly meant to be 'text models' for the students. Nevertheless, there was no explicit attempt by the teacher to draw their attention to these spoken descriptions as models. In other words, no direction was made to draw conclusion about text models. This is proven by Extract 2 in which the teacher asked about students' knowledge on the structure of written descriptive text.

Extract 2

55 Teacher : Ok, today will learn about something like descriptive. What do you know about descriptive?

56 Student : A text which uses present tense.

57 Teacher : How many generic structures are there?

58 Student : 2 
It is obvious in Extract 2 above that the teacher did not draw students' attention on the characteristics of text they previously produced in the interactions (spoken). In other words, there was no inductive reasoning elicited by the teacher. In contrast, teacher's questions drew students deductive reasoning as evident in students answer in line 55, "What do you know about descriptive?" This question elicits students to display knowledge.

Inductive reasoning was not seen because there was no link between what the students observed and what they were actually asked. The students were elicited to produce spoken descriptions which were later expected to be text model. Yet, what the teacher did to draw inferences from the spoken description was actually referring to written text. Referent to written text was obvious in Extract 3 below.

\section{Extract 3}

69 Teacher : Take a look to the sentences that I wrote on the whiteboard. Are those your sentences right?

70 Students : Yes Mam.

71 Teacher : What are the sentences made of? The tense?

72 Student : Present mam.

Student : Present tense mam.

Extract 3 shows that the teacher attempted to draw students on the structure and linguistic feature of written descriptive text by saying "the sentences I wrote on the board" (line 69). This sounded inductive reasoning, but it is not based on the 'data' the teacher presented in lines 7-54. Thus, the inductive reasoning is not elicited in these lines.

Once inductive reasoning is not manifested in lines 7-54, the next analysis of the subsequent lines looked at whether the attempt of inductive reasoning is followed by deductive reasoning. Extract 4 below shows no deductive reasoning.

\section{Extract 4}

87 Teacher ; Yeah, everything you need to write about the topic. It can be like a map

88 Student : Finish mam.

89 Teacher : Ok now, develop the topic with the map you have made into essay of descriptive.

95 Teacher : No. You may not. The last job is to find out the generic structure of the text that your group has made. 
96 Student : Still in group Mam?

97 Teacher : Yeah. Now, re-write your work.

Extract 4 show that the teacher asked students to outline a descriptive essay by using mind map. Yet, it is not clear whether the map was developed based on the (written) text structure. Looking at the data presented by Hafidah (2014) in Figure 1 below, students' mind map is not in line with the spoken descriptions.

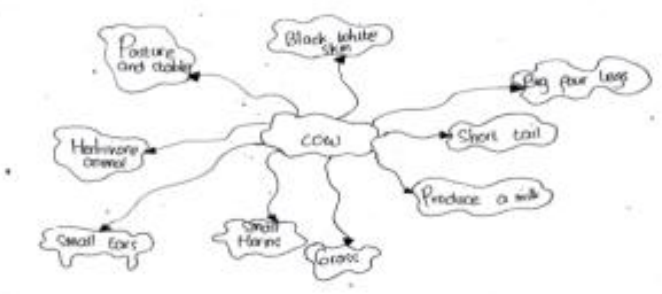

Figure 1 Mind map produced by students (Hafidah, 2014:53)

From Figure 1, it is obvious in the mind map above that it is not in line with the text talked in the BKoF (about a friend's description). This is manifested in the produced text during the ICoT activities as seen in Figure 2.

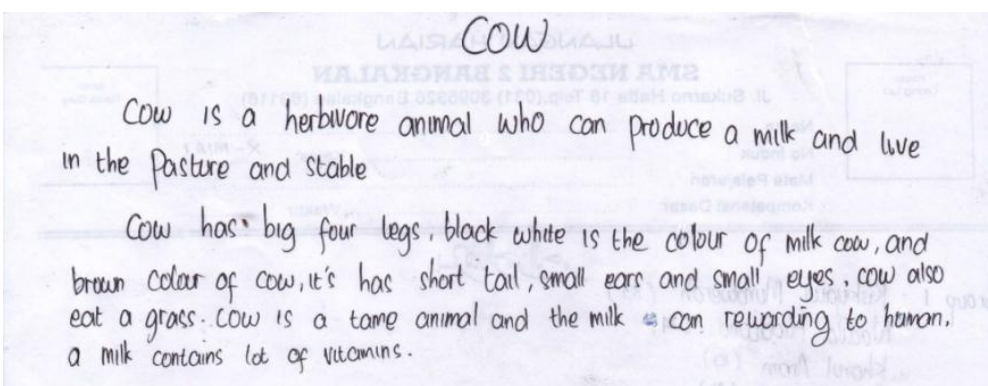

Figure 2 A description of an animal produced by students (Hafidah, 2014:54).

Figure 2 provides evidence that the produced essay is not the result of applying deductive reasoning to learn how to describe friends orally, as it was stated in the BKoF. In other words, no deductive reasoning was manifested by the teacher in the lesson. More importantly, there was a mismatch between the built 
context, the text model and the produced text. This indicates that scientific approach application as claimed by Hafidah (2014) is superficial.

The result of the analysis above can be contrasted with what has been claimed by Hafidah (2014). According to Hafidah (2014: 58), "In the observing learning experience, the students to be models ...(model here means person). By showing them ...models, she had encouraged her students to see a real phenomenon." This is the point of misunderstanding. A text model is not "real object" as understood by teacher. Hafidah (2014) adds that constructing "a descriptive text from the topic...is in line with associating learning experience proposed". In fact, the text model was not really introduced to the students and the text produced by the students in the ICoT was not in line with the so called model by Hafidah (2014).

At the heart of scientific approach, therefore, the lesson transcript has shown that the lesson's lines of reasoning to assist learners to finally produce a descriptive essay are far from the essence of scientific approach as suggested by Ary et. al. (2010). They also lack unity in terms of what was planned to learn, the text model of what to learn, the text product to produce.

\section{CONCLUSION}

This paper has argued that findings of studies on the application of scientific approach based on the 2013 curriculum could be unjustified. Through the stages of Genre-Based Approach, this paper has attempted to show that they could be the most appropriate adaptations of scientific approach in the English lesson as allowed by the Ministerial decree 103/2014. By using data of lesson transcript in Hafidah's (2014) study, this paper has shown that through a deeper analysis than superficial one, applied language researchers could explore the essence of scientific approach in the ELT classroom. Through deep analyses of teacher's use of classroom language expressions, teacher's intentions could be revealed and interpreted so that teacher's implementation of stages of SA and stages of GBA could be revealed. The missing stages of GBA show missing links among the stages, which will eventually lead to inappropriate reasoning. The results of analysis, however, show that there is no inductive-deductive reasoning 
reflected in teacher's use of classroom language. It can be concluded that there is little evidence of scientific approach in that transcribed lesson. This finding is contradictory to Hafidah's (2014) finding about SA in the lesson transcription.

To avoid similar misjudgement of the implementation of SA in English lessons, therefore, teachers and researchers are suggested to implement the stages of GBA accurately as suggested by the Teacher Book (Kemendikbud, 2014) and by proponents of GBA such as Feez and Joyce (1998), Knapp and Watkins (2005), and Hammond (2001).

\section{REFERENCES}

Ary, D., Jacobs, L. C., \& Sorensen, C. K. 2010. Introduction to research in education. Belmont, CA: Wadsword, Cengage Learning.

Badan Standar Nasional Pendidikan. 2003. Kurikulum 2004: Standar kompetensi mata pelajaran bahasa Inggris SMA dan Madrasah Aliyah. Jakarta: Badan Standar Nasional Pendidikan (BSNP).

Badan Standar Nasional Pendidikan. 2006. Standar isi mata pelajaran bahasa Inggris SMP/MTs. Jakarta: Badan Standar Nasional Pendidikan (BSNP).

Cohen, L., Manion, L., \& Morrison, K. 2007. Research methods in education (6th eds). London: Routledge.

Corbin, J., \& Strauss, A. 2008. Basics of qualitative research (3e). London: Sage Publication.

Cullen, R. 2001. The use of lesson transcripts for developing teachers' classroom language. System, 29, 27-43.

Feez, S., \& Joyce, H. 1998. Text-based syllabus design. Sydney: National Centre for English Language Teaching and Research.

Hafidah, Dwinda Putri. 2014. Scientific Approach in the Teaching of English Writing in High School. Unpublished Master of Education Thesis, Language and Literature Education Graduate Program, State University of Surabaya.

Hammond, J. (Ed.). 2001. Scaffolding teaching and learning in language and literacy education. Newton, NSW: PETA. 
Johnson, R. K. 1990. Developing teachers' language resources. In J. C. Richards \& D. Nunan (Eds.), Second language teacher education (pp. 269-281). Cambridge: Cambridge University Press.

Kemendikbud. 2014. Buku Guru Bahasa Inggris When English Rings a Bell. Jakarta: Kemendikbud

Knapp, P., \& Watkins, M. 2005. Genre, text and grammar: Technologies for teaching and assessing writing. Sydney: University of New South Wales Press.

Lemke, J. L. 1989. Using language in the classroom. Oxford: Oxford University Press.

Munir, Ahmad. 2012. Indonesian Pre-service English teachers' learning and using classroom language. Doctoral Thesis. Faculty of Education Monash University.

Pahlevi, Muhammad Reza. 2014. The Implementation Of Scientific Approach In Teaching Writing Based On The 2013 Curriculum In Junior High School. Unpublished Master of Education Thesis, Language and Literature Education Graduate Program, State University of Surabaya.

Peraturan Menteri Pendidikan dan Kebudayaan No 103 Tahun 2014 tentang Pembelajaran Pada Pendidikan Dasar dan Pendidikan Menengah.

Peraturan Menteri Pendidikan dan Kebudayaan No 65 Tahun 2013 tentang Standar Proses Kurikulum 2013.

Richards, J.C. 2001. Curriculum Development in Language Teaching. Oxford: Oxford University Press. 